\title{
Formulation of Trichoderma asperellum TV190 for biological control of Rhizoctonia solani on corn seedlings
}

Wence Herrera ${ }^{1,2}$, Oscar Valbuena ${ }^{1}$ and Domenico Pavone-Maniscalco ${ }^{1 *}$

\begin{abstract}
Environmental conditions affect biocontrol agents in a field, being appropriate formulations an alternative to overcome this problem. Formulations based on Trichoderma asperellum TV190 were prepared by emulsified mineral or vegetable oils, which protected spores from ultraviolet radiation, showing greater viability of $37-43 \%$ (mineral) and $56-63 \%$ (vegetable) than the control (8-12\%). These formulations improved an antagonism of T. asperellum on Rhizoctonia solani under greenhouse conditions, reducing infected corn seedlings by $72 \%$ (mineral) and 59\% (vegetable). Necrotic spot size was reduced by $90.04 \%$ (mineral) and $87.29 \%$ (vegetable). A granular formulation, prepared with degreased corn germ and $T$. asperellum spores, protected the corn seedlings from $R$. solani under greenhouse conditions, with $73 \%$ reduction of infected plants and $93 \%$ reduction of necrotic spot size. Both granular and liquid formulations were able to improve T. asperellum antagonism, suggesting that these formulations could be included in agricultural pest control strategies.
\end{abstract}

Keywords: Zea mays, Trichoderma asperellum, Antagonistic fungi, Granular formulation, Liquid formulation, Ultraviolet UV protection

\section{Background}

Corn (Zea mays L.) is one of the most important cereals in the world. The production of this crop is affected by biotic and abiotic factors, where phytopathogenic fungi play an important role by decreasing production levels and generating global economic losses. The phytopathogenic fungus Rhizoctonia solani (Kühn) is a major pest in corn attacking all belowground plant parts, including seeds, hypocotyls, and roots (Da Silva et al. 2017). In maize, $R$. solani is the causal agent of banded leaf and sheath blight, albeit other symptoms like stalk lesions (rind spotting), stalk breakage, clumping and caking of styles (silk fibers), horseshoe-shaped lesions with banding on caryopses, and sclerotial formation on styles, glumes, cupules, and caryopses have been reported

\footnotetext{
* Correspondence: dfpavone@yahoo.it

'Centro de Biotecnología Aplicada (CBA), Departamento de Biología, Facultad de Ciencias y Tecnología (FACYT), Universidad de Carabobo, Campus de Bárbula, Municipio Naguanagua, Estado Carabobo, Venezuela Full list of author information is available at the end of the article
}

(Chander and Payak 1982). Consequently, it has required the implementation of control measures, especially the chemicals, which have environmental and health implications (Kim et al. 2017).

Application of living organisms for pest control is an alternative to the use of agrochemicals. Biological control of $R$. solani using Trichoderma spp. is a real alternative to the use of agrochemicals. In in vitro tests, antagonism was registered from Trichoderma spp. against this phytopathogen (Wang and Zhuang 2019). Field applications of Trichoderma spp. have demonstrated a positive effect on biocontrol of $R$. solani (Barnett et al. 2019). However, field environmental conditions are still one of the main limitations for the use of biocontrol agents (Bashan et al. 2014). Parameters such as ultraviolet radiation (UVR) (Costa et al. 2016), relative humidity (Swaminathan et al. 2016), temperature (Domingues et al. 2016), and storage conditions (Locatelli et al. 2018) could have a negative influence on inoculum viability. Using appropriate formulations is a way to overcome this problem, which create 
microclimates that protect spores from adverse environmental conditions (Doni et al. 2014).

Formulations of biological control agents can be classified in (a) dry powders, (b) granules, and/or (c) wettable powders. Additionally, the use of adherents such as oil, gelatin, and gum as well as humectants such as propylene glycol and polyethylene glycol has been used to reduce evaporation (Zhang et al. 2016).

Application of biocontrol agents using a suitable formulation that protects the inoculum against UV radiation is the main objective of this work, proposing liquid and granular formulations based on Trichoderma asperellum spores to control $R$. solani under in vitro and greenhouse conditions.

\section{Materials and methods} Fungal strains and seeds

Trichoderma asperellum (TV190) isolated from maize fields of Monagas State, Venezuela (Pavone and Dorta 2015), was obtained from the Centro de Biotecnología Aplicada (CBA), Universidad de Carabobo, Venezuela. The strain was maintained by alternate subculture on sterile soil and potato dextrose agar (PDA) plates. $R$. solani strain P2AB2 (AG1-IA) was donated by Dr. Alex González (Fundación DANAC) San Felipe, Venezuela, and maintained by subculture on PDA plates. White corn seeds $\mathrm{H} 2020$ were donated by "Semillas Híbridas de Venezuela C.A." (SEHIVECA).

\section{Granulated formulation}

Degreased corn germ (DCG), donated by "Refinadora de Maíz Venezolana" (REMAVENCA) Aragua State, Venezuela, was sterilized at $120^{\circ} \mathrm{C}$ for $30 \mathrm{~min}$ in an autoclave and inoculated with the necessary volume of a $T$. asperellum spore suspension in water $\left(10^{6}\right.$ spores/g) to reach a final water content of $50 \%(\mathrm{w} / \mathrm{w})$. Preparation was mixed and processed through a meat grinder with a 4-mm screen. Finally, the preparation was air-dried to a moisture content of $8 \%(\mathrm{w} / \mathrm{w})$ and stored at $8{ }^{\circ} \mathrm{C}$ for $24 \mathrm{~h}$ until use.

\section{Liquid formulation}

Formulations were prepared using $20 \mathrm{ml}$ of vegetal oil (VO) Vatel ${ }^{\circ}, 10 \mathrm{ml}$ of Surfatron ${ }^{\circ}$, and $970 \mathrm{ml}$ of water. Alternatively, emulsified mineral oil (MO) Aceite Blanco ${ }^{\circ}$ was diluted in water according to the manufacturer's instructions $(20 \mathrm{ml} / \mathrm{l})$. Lignosulfonate $(1 \% \mathrm{w} / \mathrm{v})$ was also added as UVR filter. Concentration of T. asperellum was adjusted to $10^{6}$ spores $/ \mathrm{ml}$. A T. asperellum spore suspension in pure water was used as the negative control. Liquid formulations were used immediately after preparation.

\section{Viability of $T$. asperellum spores}

Water agar plates $(1.7 \% \mathrm{w} / \mathrm{v})$ were inoculated with 0.1 $\mathrm{ml}$ spore suspensions (formulated or not). Plates were incubated at $25 \pm 2{ }^{\circ} \mathrm{C}$ for $20 \mathrm{~h}$ in the dark. Germinated spores were counted, using a stereoscopic microscope ( $\times 400)$, in 3 individual plates (replicates), 100 spores in each one.

\section{Effect of ultraviolet radiation (UVR) on $T$. asperellum spores}

In plates prepared as in viability assays, spores were exposed to UVR in uncovered plates. Exposition to UVR was performed using a lamp Model UVLMS-38, UVP ${ }^{\circ}$ (Ultra-Violet Products), with wavelengths of $254 \mathrm{~nm}$ (UV-C) and $302 \mathrm{~nm}$ (UV-B) applied separately. Intensities used for UV-B and UV-C were $1900 \mu \mathrm{W} / \mathrm{cm}^{2}$ and $250 \mu \mathrm{W} / \mathrm{cm}^{2}$ for 1,2 , and $5 \mathrm{~min}$, respectively. UVR measurements were performed by a UVP ${ }^{\oplus}$ Model UVX radiometer, equipped with 3 sensors (Models UVX-25, UVX-36, and UVX-31). After irradiation, plates were incubated for $18-24 \mathrm{~h}$ and viability was evaluated.

\section{Effect of liquid and granular formulations on $R$. solani}

White corn seeds were planted in bags $(15 \mathrm{~cm}$ diameter $\times 20 \mathrm{~cm}$ tall) in soil, and irrigated daily. After 10 days, a $R$. solani scletoria, obtained from PDA plates grown for 8 days, was placed on a plant bud. Immediately, $1.5 \mathrm{ml}$ of the liquid formulations (emulsions with $10^{6} \mathrm{~T}$. asperellum spores $/ \mathrm{ml}$ ) or a granule of the solid formulation (approximately $0.1 \mathrm{~g}$ ) was added to the infected bud. Water was sprayed daily to maintain high relative humidity. Plants with $R$. solani sclerotia without Trichoderma and emulsions or granules without T. asperellum spores were used as controls. Treatments consisted of 30 plants. After 3 to 8 days in open greenhouse conditions (average temperature $30^{\circ} \mathrm{C}$ ), the number of infected plants and the necrotic spot size produced by $R$. solani on leaf were evaluated. The reduction in the number of infected plants $\left[\left(1-\frac{\text { number of infected plants in treatments }}{\text { number of infected plants in control }}\right)\right.$ $\times 100]$ and the decrease in necrotic spot size (NSS) caused by $T$. asperellum $\left[\left(1-\frac{\text { NSS in treatments }}{\text { NSS in control }}\right) \times 100\right]$ were also calculated.

Despite $R$. solani is a soil-borne pathogen, sclerotia was inoculated on the plant bud because it demonstrated a high infection rate on corn plants than the experiments inoculating $R$. solani on soil, with very clear and evident symptoms. Additionally, using $R$. solani as leaf pathogen was more suitable to evaluate the effect of UVR. This method is very convenient albeit it is clear to be only an approach previous to field validation on natural conditions.

\section{Statistical analysis}

Mean and standard error were calculated for each treatment. Variance analysis (ANOVA) was performed in order to detect significant differences between treatments. In case of not fulfilling the assumptions for the ANOVA, non-parametric tests were performed (Kruskal-Wallis). A 
comparison of means (Tukey) was also performed. The statistical package used was Past 3.1 (Hammer et al. 2001). All experiments were repeated three times.

\section{Results and discussion Oil formulations}

One of the first steps for implementing the formulations with biocontrol fungi was to determine its compatibility with the microorganisms involved in the study. The percentage of T. asperellum TV190 spore germination in oil formulations without irradiation were 95.32, 96, and $97.66 \%$, for the mineral oil (MO), vegetable oil (VO), and control, respectively (Figs. 1 and 2). It was observed that $T$. asperellum and emulsions seemed to be compatible, with non-significant differences $(F=0.018 ; \mathrm{df}=4 ; P$ $=0.99$ ) between spore germination in formulations with mineral or vegetable oil. For the treatments with spores, exposed to UVR, a negative effect was evident on spore viability. Statistical differences were found in treatments with MO under UVB $(F=109$; df: $32 ; P<0.05)$ and UVC $(F=132.82$; df: $32 ; P<0.05)$ and VO under UVB $(F=176.3$; df: $32 ; P<0.05)$ and UVC $(F=132.39$; df: 32; $P<0.05)$. In general, UVR decreased spore viability to $8-12 \%$ levels after 5 min of treatment on unformulated T. asperellum spores (NF), the effect being dependent on time exposure (Figs. 1 and 2).

However, in systems treated with oil formulations, partial protective effects were detected. After $5 \mathrm{~min}$ UVR exposure, viability decreased to $43-56 \%$ in systems with $\mathrm{MO}$ and to $56-63 \%$ in VO systems (Figs. 1 and 2). Once again, the negative effect was dependent on the exposure time. In treatments with lignosulphonate, nonsignificant differences were detected in the combination with VO under the same time of exposure to UVR $(F=$ 0.16; $\mathrm{df}=5 ; P=0.71$ ) (Fig. 2), while in the treatments with $\mathrm{MO}$, differences were detected only when spores were exposed to UVB $(F=24.89$; $\mathrm{df}=5 ; P<0.05)$ or $\mathrm{UVC}(F=4.84 ; \mathrm{df}=5 ; P<0.05)$ for 5 min (Fig. 1$)$.

Results strongly suggested a protective effect of oil formulations and lignosulfonate to T. asperellum spores, when irradiated with UVR under laboratory conditions. Exposure time was a crucial parameter because spore viability was drastically reduced, when exposure increases from 1 to $5 \mathrm{~min}$. A greater negative effect of UV-C radiation was also evident in spore viability. The UVR effect on fungal metabolism was related to DNA degradation in conidia and mycelium of Aspergillus nidulans (Braga et al. 2015). In addition, Seyedmousavi et al. (2014) reported that UVR affected proteolytic activity, cell growth, and carbohydrate synthesis in Candida albicans. Besides, it had also been reported that UV-B inhibited various fungal processes such as spore germination and hyphae elongation (Suthaparan et al. 2016) and affects negatively several fungi such as
Botryris cinerea (Janisiewicz et al. 2016). Mutagenesis has been induced using UVR to obtain modifications in the genetic structure of two Trichoderma biocontrol agents, T. virens and T. asperellum (Alfiky 2019). If exposure time was longer, DNA damage will be great, producing a higher rate of mutations and reduced spore germination (Begum et al. 2009). UV-C radiation reduced the spore germination by more than $80 \%$ (Bell and Wheeler 1986). A decrease in spore viability by UVR depends on spore coloration, the medium in which it was evaluated, and time of exposure to radiation, the darker the spore, the greater its resistance to UV radiation, probably due to melanin that protects it from this radiation (Carzaniga et al. 2002). The photoprotective properties of melanin were considered to be important for the survival and longevity of spores (Bell and Wheeler 1986).

A protective effect of oil formulations against UVR has also been reported in other studies (Fernandes et al. 2015), observing mineral and vegetable oil protection on entomopathogenic fungi spores against UVR. Several oil-based formulations with T. asperellum have been developed to control cacao black pod disease caused by Phytophthora megakarya, in which the half-life of the conidia reached 22.5 and 5 weeks in aqueous and oil suspension, respectively (Mbarga et al. 2014). Oil and aqueous formulations have been proven to control frosty pod rot caused by Moniliophthora roreri on cocoa (Crozier et al. 2015), finding that an inverted corn oil formulation significantly enhanced cocoa yield, providing a promising model for optimizing Trichoderma-based biocontrol strategies. Finally, some vegetable oils are able to absorb UV radiation (Montenegro and Santagati 2019) suggesting the possibility to use them as UV blockers.

\section{Greenhouse assays}

The ability of $T$. asperellum formulations (granular and liquid) to control $R$. solani was evaluated by determining the number of infected plants and necrotic spot size (NSS) on corn leaves. Results showed statistical differences in treatments with $T$. asperellum $(F=1875.892$; df $=29 ; P<0.05)$ producing a decrease in the number of infected plants after being treated with $T$. asperellum (Fig. 3). The number of infected plants was similar (70\%) in treatments with oil formulations ( $\mathrm{MO}$ and $\mathrm{VO})$ and with granules (G), both without T. asperellum, and in the treatment with $R$. solani alone $(\mathrm{R})(F=13.63$; $\mathrm{df}=8$; $P=0.2$ ). After applying $T$. asperellum spores to oil formulations (MOT and VOT) or to granules (GTR), the percentage of infected plants decreased to 20, 29, and $19 \%$, respectively. The number of infected plants was reduced by $72 \%$ (MOT), 59\% (VOT), and 73\% (GTR).

Necrotic spot size (NSS) produced by $R$. solani on corn seedlings was another evaluated parameter (Fig. 4). Treatments without $T$. asperellum resulted in spot sizes 


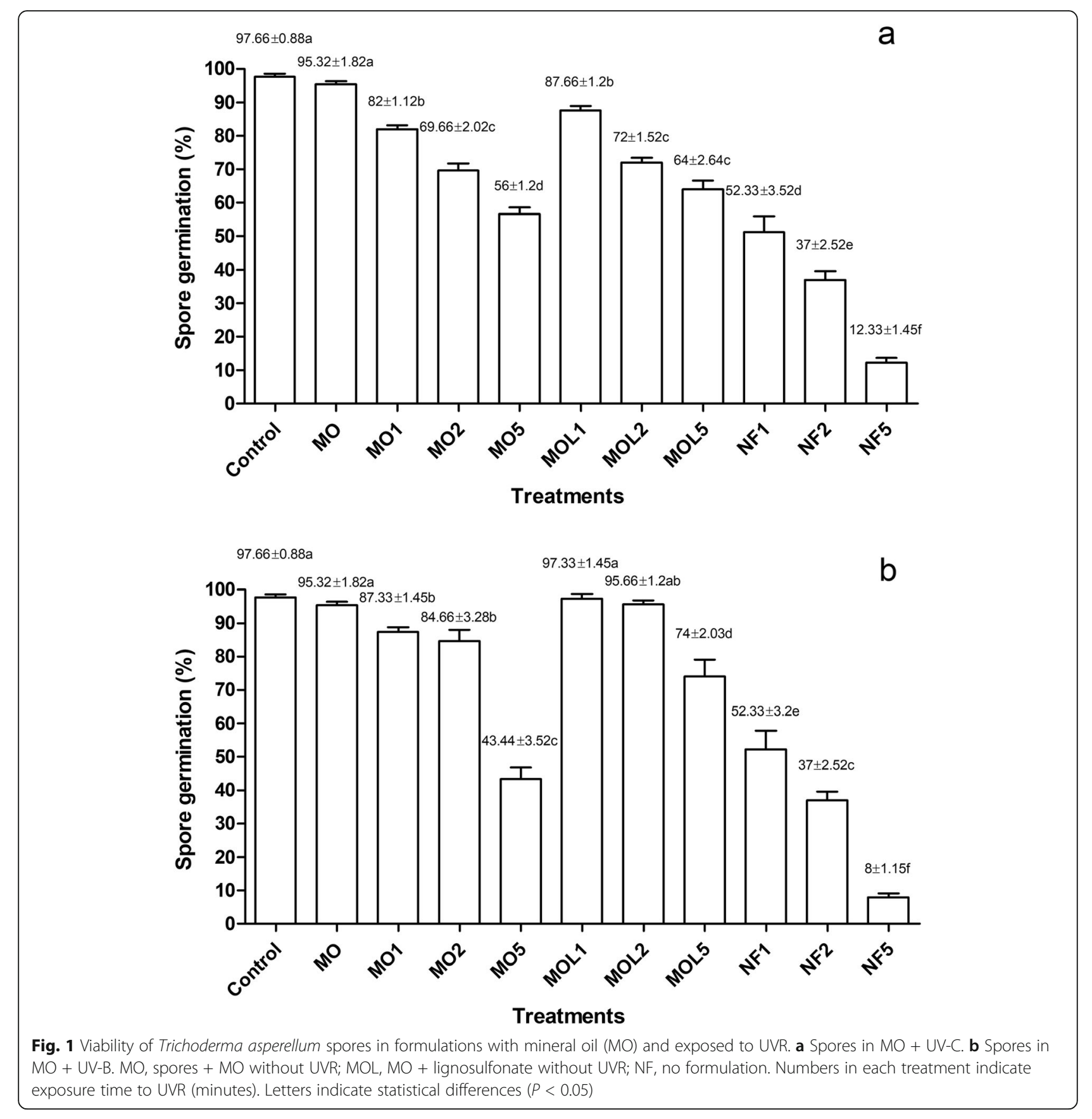

larger than $20 \mathrm{~mm}(\mathrm{MO}=26.8 \mathrm{~mm}, \mathrm{VO}=28.31 \mathrm{~mm}$, $\mathrm{GR}=20.33 \mathrm{~mm}, \mathrm{R}=27.53 \mathrm{~mm})$. In contrast, by using $T$. asperellum without formulation, NSS was $12.23 \mathrm{~mm}$. When T. asperellum was included in oil formulations, spot size decreased to $2.67 \mathrm{~mm}$ (MOT) and $3.6 \mathrm{~mm}$ (VOT), with significant differences in relation to other treatments $(H=113.972$; df $=9 ; P<0.05)$, but not with each other $(F=0.222$; df $=1 ; P=0.64)$. The decrease in spot size caused by $T$. asperellum was $55.58 \%$, when applied alone, compared to 90.04 and $87.29 \%$, when applied with MO or VO, respectively. In GTR formulation, spot size decreased to $1.36 \mathrm{~mm}$ (93.32\%).

In greenhouse assays, $R$. solani incidence was evaluated when liquid and granular formulations were applied. However, it is not possible to determine if the effect observed is due to the protection they exert against the UVR, since it was not possible to determine how much radiation these spores received. Obtained results were similar to those of Battan (2004) who used an oil formulation of $T$. harzianum to evaluate its 


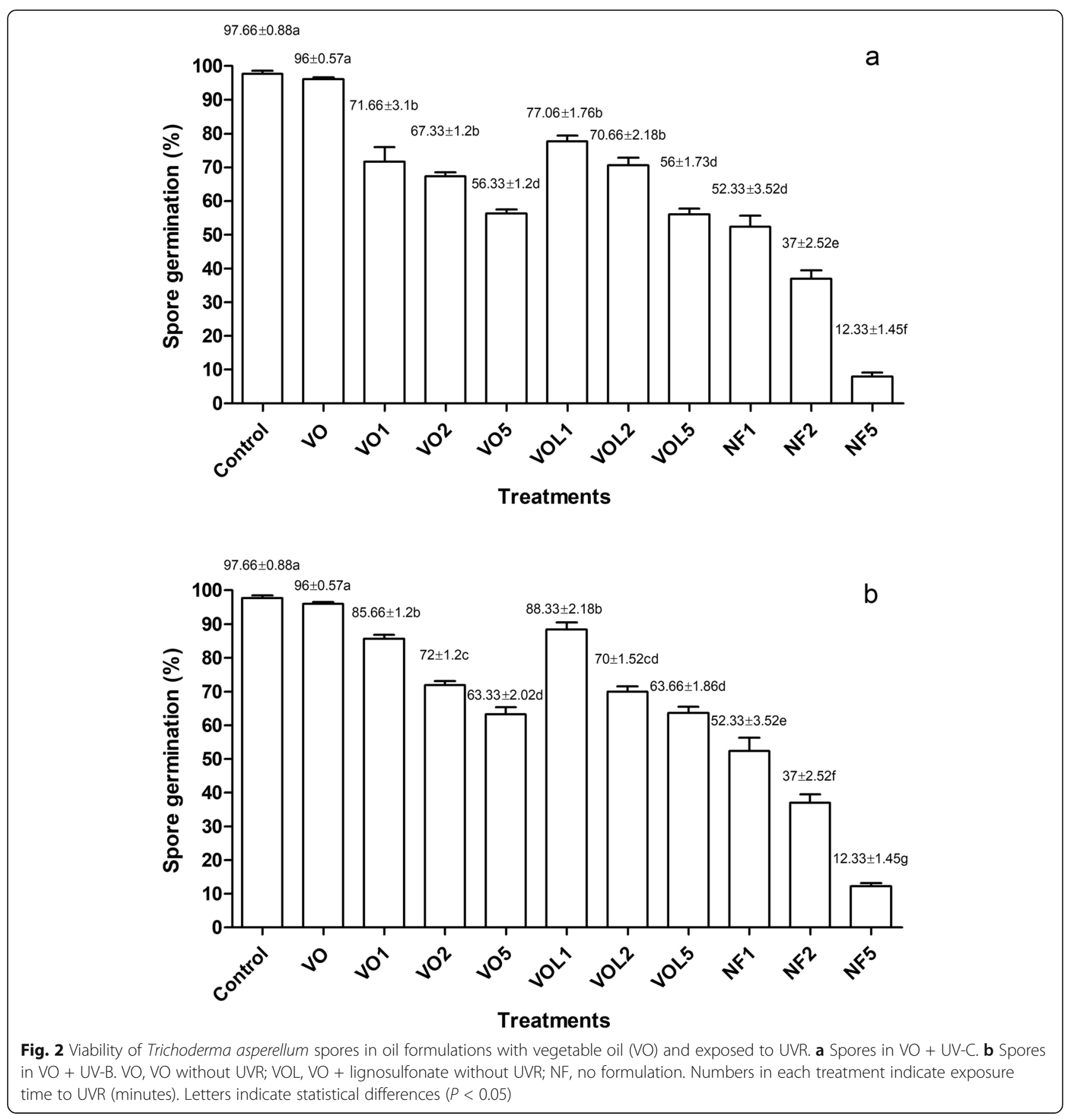

biocontrol effect on Rhizopus stolonifer, Botrytis cinerea, and Penicillium expansum, fungi that affected apple, peach, pear, and strawberry. Although it was not studied in this work, one of the objectives of granular formulation was to serve as a substrate for fungal sporulation to increase spore number. The substrate used for granular formulation (DCG) has been characterized by the manufacturer containing $65.06 \%$ carbohydrates, $13.82 \%$ protein, $10.97 \%$ water content, $5.37 \%$ crude fiber, $4.19 \%$ of ash, and $0.59 \%$ of fats. It was also rich in minerals such as phosphorus, magnesium, iron, and zinc. DCG could be an excellent substrate for sporulation of several filamentous fungi. In this sense, a granulated formulation with DCG using the entomopathogenic fungus Nomurea rileyi spores was used to increase inoculum over 600 times and to protect spores from UVR (Pavone et al. 2009), probably because spores were immersed within a granule matrix, where UVR cannot reach them. Protection exerted by granule against UVR could be important for maintaining inoculum viability in the field.

Extruded granular formulations, containing rice flour, gluten, and biomass of Gliocladium virens and Trichoderma 


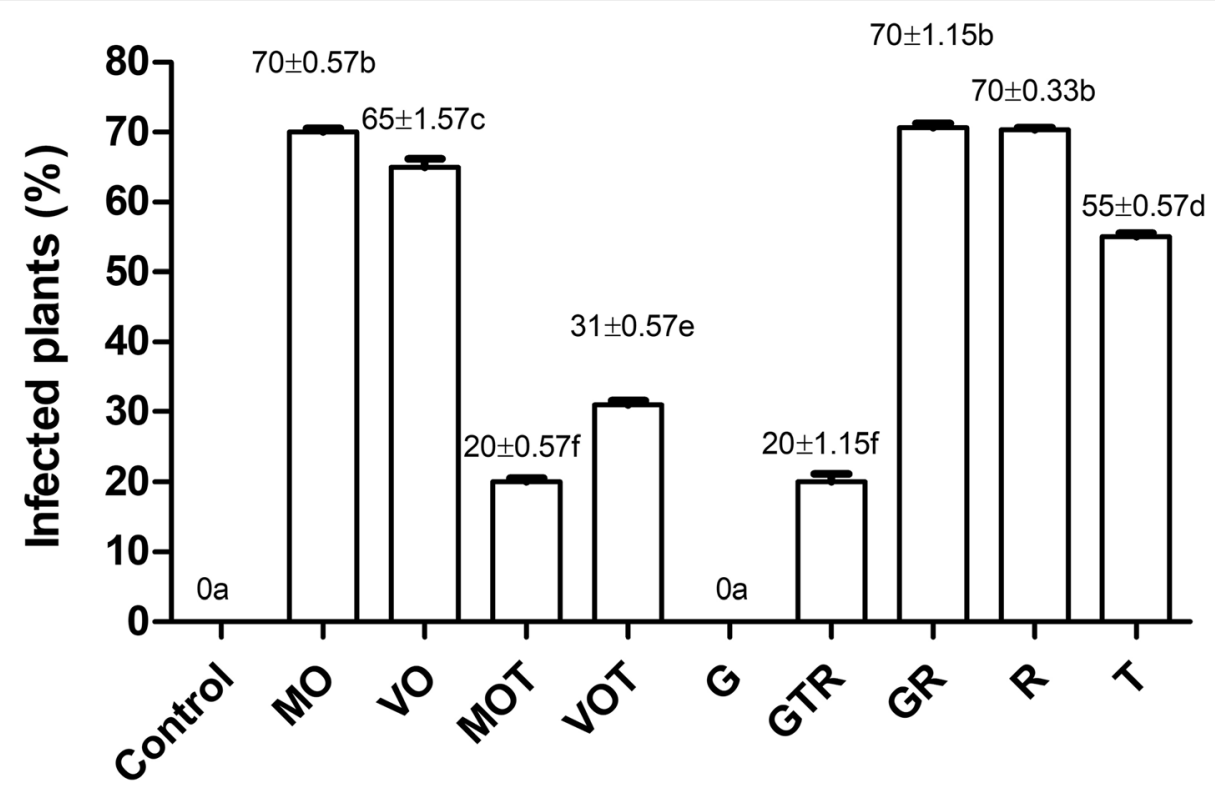

Treatments

Fig. 3 Corn seedlings infected with R. solani. MO, mineral oil without Trichoderma asperellum or Rhizoctonia solani; VO, vegetable oil without T. asperellum or R. solani; MOT, mineral oil with T. asperellum; VOT, vegetable oil with T. asperellum; G, granular formulation without $T$. asperellum or R. solani; GTR, granular formulation with $T$. asperellum; GR, granular formulation without T. asperellum; $R$, $R$. solani without treatment; T T. asperellum without formulation. Letters indicate statistical differences

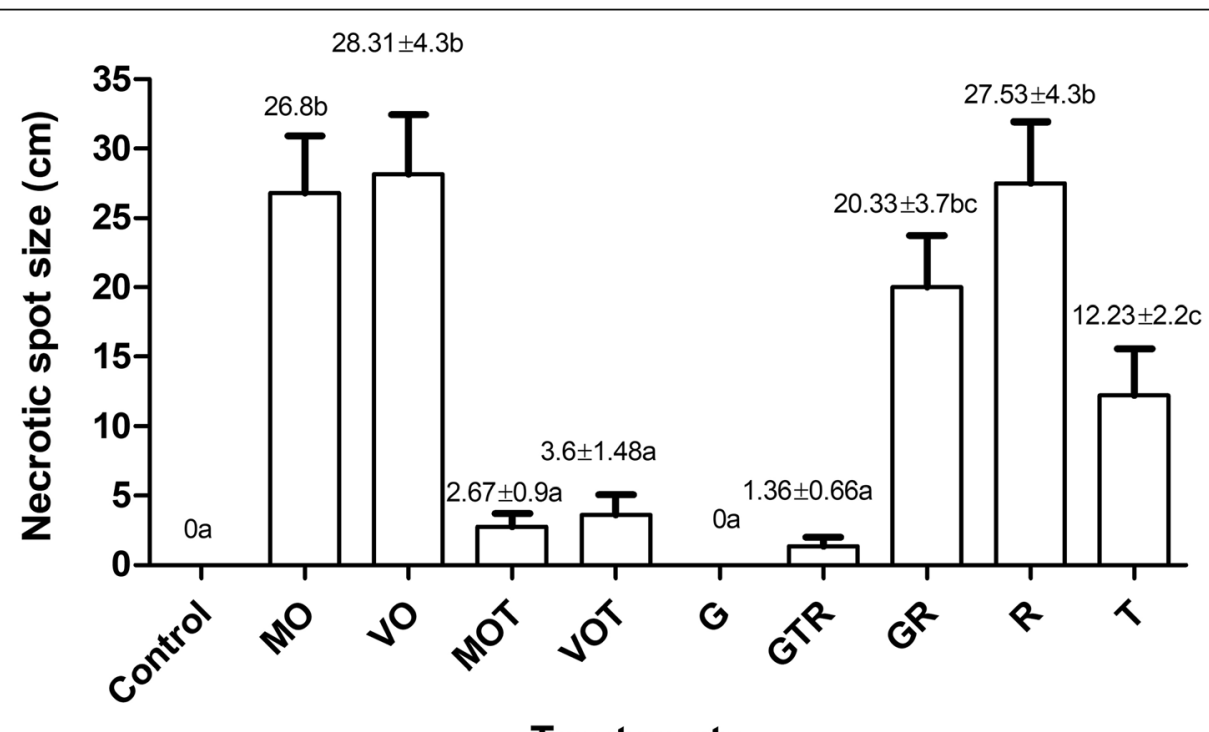

\section{Treatments}

Fig. 4 Necrotic spot size produced by Rhizoctonia solani in corn seedlings. MO, mineral oil without Trichoderma asperellum or $R$. solani; VO, vegetable oil without $T$. asperellum or R. solani; MOT, mineral oil with $T$. asperellum; VOT, vegetable oil with $T$. asperellum; G, granular formulation without T. asperellum or R. solani; GTR, granular formulation with T. asperellum; GR, granular formulation without T. asperellum; $R$, $R$. solani without treatment; T, T. asperellum without formulation. Letters indicate statistical differences 
spp. among other components reduced eggplant dampingoff caused by Rhizoctonia solani (Lewis and Larkin 1997). Formulations prepared with several components like talc and lignite were produced for seed treatment and control of tomato damping-off caused by Pythium aphanidermatum, in which active colonization of T. harzianum in the rhizosphere was observed (Jayaraj et al. 2006). Microencapsulation has been proposed to prolong shelf life and enhance application efficiency of Trichoderma (Cumagun 2014) focusing on seed treatment using solid matrix priming, liquid coating, and double coating.

It will be important to test these formulations under field conditions to obtain conclusive results that will allow their use as commercial products. Formulation compatibility with other control measures such as insecticides and herbicides commonly used in field should also be evaluated. Due to its mode of action and good performance under in vitro and greenhouse conditions, protecting spore against UVR and plants from $R$. solani, oil and granular formulation seems to have great potential to be incorporated in Integrated Pest Management Programs.

\section{Conclusions}

Obtained results evidenced a great potential to use $T$. asperellum in liquid and granular preparations. Oil formulations efficiently protected $T$. asperellum spores from UVR (UV-B and UV-C) in vitro. Lignosulphonate enhanced spore protection against UVR, only when applied with MO. It was also verified that oil and granulated formulations improve $T$. asperellum performance in protecting corn seedlings from $R$. solani attack under greenhouse conditions. Fungal formulations should become a standard in biocontrol applications in order to increase efficacy.

\section{Abbreviations \\ DCG: Degrease corn germ; G: Granular formulation without T. asperellum or R. solani; GR: Granular formulation without T. asperellum with R. solani; GTR: Granular formulation with T. asperellum and R. solani; MO: Mineral oil; MOL: Mineral oil with lignosulfonate; MOT: Mineral oil with Trichoderma; NF: No formulation; NSS: Necrotic spot size; PDA: Potato dextrose agar; R: $R$. solani without treatment; T: T. asperellum without formulation with $R$. solani; UVR: Ultraviolet radiation; VO: Vegetable oil; VOL: Vegetable oil with lignosulfonate; VOT: Vegetable oil with Trichoderma}

\section{Acknowledgements}

The authors would like to express their gratitude to Dr. Blas Dorta (Universidad Central de Venezuela) for the equipment used in UVR assays and to Dr. Alex González (Fundación Danac) for the R. solani strain and Semillas Hibridas de Venezuela (SEHIVECA) for the corn seeds used in this work.

\section{Authors' contributions}

WH: Collection and/or assembly of data; data analysis and interpretation; writing the article; critical revision of the article. OV: Writing the article; critical revision of the article. DP: Research concept and design; data analysis and interpretation; writing the article; critical revision of the article. The authors read and approved the final manuscript.

\section{Funding}

Resources from Centro de Biotecnología Aplicada were used for this research.

\section{Availability of data and materials}

The datasets used and/or analyzed during the current study are available from the corresponding author on reasonable request.

\section{Ethics approval and consent to participate}

Not applicable.

\section{Consent for publication}

Not applicable.

\section{Competing interests}

The authors declare that they have no competing interests.

\section{Author details}

${ }^{1}$ Centro de Biotecnología Aplicada (CBA), Departamento de Biología, Facultad de Ciencias y Tecnología (FACYT), Universidad de Carabobo, Campus de Bárbula, Municipio Naguanagua, Estado Carabobo, Venezuela. ${ }^{2}$ Present address: Doctoral Program in Sciences of Natural Resources, Universidad de La Frontera, Temuco, Chile.

Received: 8 January 2020 Accepted: 3 April 2020

Published online: 20 April 2020

\section{References}

Alfiky A (2019) Effects of ultraviolet irradiation on the in vitro antagonistic potential of Trichoderma spp. against soil-borne fungal pathogens. Heliyon 5(7):e02111. https://doi.org/10.1016/j.heliyon.2019.e02111

Barnett S, Ballard R, Franco C (2019) Field assessment of microbial inoculants to control Rhizoctonia root rot on wheat. Biol Control 132:152-160. https://doi. org/10.1016/j.biocontrol.2019.02.019

Bashan Y, de Bashan L, Prabhu S, Hernandez JP (2014) Advances in plant growthpromoting bacterial inoculant technology: formulations and practical perspectives (1998-2013). Plant Soil 378:1-33. https://doi.org/10.1007/s11104013-1956-X

Battan Y (2004) Effect of treatment with Trichoderma harzianum Rifai formulated in invert emulsion on postharvest decay of apple blue mold. Int J Food Microbiol 96:281-288. https://doi.org/10.1016/j.jifoodmicro.2004.04.002

Begum M, Hocking A, Miskelly D (2009) Inactivation of food spoilage fungi by ultraviolet (UVC) irradiation. Int J Food Microbiol 129:74-77

Bell A, Wheeler M (1986) Biosynthesis and function of melanin. Annu Rev Phytopathol 24:411-451

Braga G, Rangel D, Fernandes É, Flint S, Roberts D (2015) Molecular and physiological effects of environmental UV radiation on fungal conidia. Curr Genet 61(3):405-425

Carzaniga R, Fiocco D, Bowyer P, O' Connell R (2002) Localization of melanin in conidia of Alternaria alternata using phage display antibodies. Mol Plant Microbe In 15:216-224. doi: https://doi.org/10.1094/MPMI.2002.15.3.216.

Chander S, Payak M (1982) Symptoms and signs of banded leaf and sheath blight of maize. Phytoparasitica 10(1):41-49. https://doi.org/10.1007/ BF02981891

Costa L, Morandi M, Stricker S, Bettiol W (2016) UV-B radiation reduces biocontrol ability of Clonostachys rosea against Botrytis cinerea. Biocontrol Sci Techn 26(12):1736-1749. https://doi.org/10.1080/09583157.2016.1241981

Crozier J, Arroyo C, Morales H, Melnick R, Strem M, Vinyard B, Collins R, Holmes K, Bailey (2015) The influence of formulation on Trichoderma biological activity and frosty pod rot management in Theobroma cacao. Plant Pathol 64(6): 1385-1395. https://doi.org/10.1111/ppa.12383

Cumagun C (2014) Advances in formulation of Trichoderma for biocontrol. In: Gupta V, Schmoll M, Herrera-Estrella A, Upadhyay R, Druzhinina I, Tuohy M (eds) Biotechnology and Biology of Trichoderma, 1st edn. Elsevier, Amsterdam, pp 527-531. https://doi.org/10.1016/B978-0-444-59576-8.00039-4

Da Silva M, Tylka G, Munkvold G (2017) Seed treatment effects on maize seedlings coinfected with Rhizoctonia solani and Pratylenchus penetrans. Plant Dis 101:957-963. https://doi.org/10.1094/PDIS-10-16-1417-RE

Domingues M, Moura K, Salomão D, Elias L, Patricio F (2016) Effect of temperature on mycelial growth of Trichoderma Sclerotinia minor and $\mathrm{S}$. 
sclerotiorum, as well as on mycoparasitism. Summa Phytopathologica 42(3): 222-227. https://doi.org/10.1590/0100-5405/2146

Doni F, Isahak A, Zain C, Ariffin S, Mohamad W, Yusoff W (2014) Formulation of Trichoderma sp. SL2 inoculants using different carriers for soil treatment in rice seedling growth. Springer Plus 3(1):532. https://doi.org/10.1186/21931801-3-532

Fernandes É, Rangel D, Braga G, Roberts D (2015) Tolerance of entomopathogenic fungi to ultraviolet radiation: a review on screening of strains and their formulation. Curr Genet 61(3):427-440. https://doi.org/10. 1007/s00294-015-0492-z

Hammer Ø, Harper D, Ryan P (2001) PAST: Paleontological statistics software package for education and data analysis. Paleontologia Electronica 4(1):9: http:// palaeo-electronica.org/2001_1/past/issue1_01.htm. Accessed: Jul 012019.

Janisiewicz W, Takeda F, Glenn D, Camp M, Jurick W (2016) Dark period following UV-C treatment enhances killing of Botrytis cinerea conidia and controls gray mold of strawberries. Phytopathology 106(4):386-394. https://doi.org/10. 1094/PHYTO-09-15-0240

Jayaraj J, Radhakrishnan N, Velazhahan R (2006) Development of formulations of Trichoderma harzianum strain M1 for control of damping-off of tomato caused by Pythium aphanidermatum. Arch Phytopathol Plant Protect 39(1):1-8. https:// doi.org/10.1080/03235400500094720

Kim K, Kabir E, Jahan S (2017) Exposure to pesticides and the associated human health effects. Sci Total Environ 575:525-535. https://doi.org/10.1016/j. scitotenv.2016.09.009.

Lewis J, Larkin R (1997) Extruded granular formulation with biomass of biocontrol Gliocladium virens and Trichoderma spp. to reduce damping-off of eggplant caused by Rhizoctonia solani and saprophytic growth of the pathogen in soil-less mix. Biocontrol Sci Techn 7(1):49-60. https://doi.org/10.1080/ 09583159731036

Locatelli G, Dos Santos G, Botelho P, Luna C, Avallone L (2018) Development of Trichoderma sp. formulations in encapsulated granules (CG) and evaluation of conidia shelf-life. Biol Control 117:21-29. https://doi.org/10.1016/j. biocontrol.2017.08.020

Mbarga J, Begoude B, Ambang Z, Meboma M, Kuate J, Schiffers B, Ewbank W, Dedieu L, Ten Hoopen G (2014) A new oil-based formulation of Trichoderma asperellum for the biological control of cacao black pod disease caused by Phytophthora megakarya. Biol Control 77:15-22. https://doi.org/10.1016/j. biocontrol.2014.06.004

Montenegro L, Santagati L (2019) Use of vegetable oils to improve the sun protection factor of sunscreen formulations. Cosmetics 6:25. https://doi.org/ 10.3390/cosmetics6020025

Pavone D, Díaz M, Trujillo L, Dorta B (2009) A granular formulation of Nomuraea rileyi Farlow (Samson) for the control of Spodoptera frugiperda (Lepidoptera: Noctuidae). Interciencia 34(2):130-134. Available in: https://www.interciencia. net/wp-content/uploads/2018/01/130-c-DORTA-5.pdf. Accessed: 25 Feb 2018.

Pavone D, Dorta B (2015) Diversidad del hongo Trichoderma spp. en plantaciones de maíz de Venezuela. Interciencia 40(1):23-31. Available in: https//www.interciencia.net/ wp-content/uploads/2017/10/23-DORTA-40-01.pdf. Accessed: 24 June 2019.

Seyedmousavi S, Hashemi S, Rezaie S, Fateh M, Djavid G, Zibafar E, Morsali F, Zand N, Alinaghizadeh M, Ataie-Fashtami L (2014) Effects of low-level laser irradiation on the pathogenicity of Candida albicans: in vitro and in vivo study. Photomed Laser Surg 32(6):322-329. https://doi.org/10.1089/pho.2012.3387

Suthaparan A, Solhaug K, Stensvand A, Gislerød H (2016) Determination of UV action spectra affecting the infection process of Oidium neolycopersici, the cause of tomato powdery mildew. J Photoch Photobio B 156:41-49. https:// doi.org/10.1016/j.jphotobiol.2016.01.009

Swaminathan J, van Koten C, Henderson H, Jackson T, Wilson M (2016) Formulations for delivering Trichoderma atroviridae spores as seed coatings, effects of temperature and relative humidity on storage stability. J Appl Microbiol 120(2):425-431

Wang C, Zhuang W (2019) Evaluating effective Trichoderma isolates for biocontrol of Rhizoctonia solani causing root rot of Vigna unguiculata. J Integr Agric 18(9):2072-2079. https://doi.org/10.1016/S2095-3119(19)62593-1

Zhang L, Zhang X, Zhang Y, Wu S, Gelbič I, Xu L, Guan X (2016) A new formulation of Bacillus thuringiensis: UV protection and sustained release mosquito larvae studies. Sci Rep 6:39425. Available at: https://www.nature. com/articles/srep39425.pdf. Accessed on 12 Sept 2017.

\section{Publisher's Note}

Springer Nature remains neutral with regard to jurisdictional claims in published maps and institutional affiliations.

\section{Submit your manuscript to a SpringerOpen ${ }^{\circ}$ journal and benefit from:}

- Convenient online submission

- Rigorous peer review

- Open access: articles freely available online

- High visibility within the field

- Retaining the copyright to your article

Submit your next manuscript at $\boldsymbol{\sim}$ springeropen.com 